\title{
Rethinking the Justice of God With Asian Sensibilities
}

\author{
Clarence Devadass \\ Catholic Research Centre, Kuala Lumpur, Malaysia. \\ clarence@archkl.org
}

\begin{abstract}
:
This article proposes the need to rethink the concepts of justice with Asian sensibilities. For centuries the idea of justice has been read and interpreted along and within the classical Greek philosophical framework. In some ways, this Greek categorial framework is also seen in the concepts of biblical justice. However, in an Asian context, the character justice and its application need to be explored in the light of restoring harmony, with the self, other, cosmos and God, which is integral in many of the Asian spiritualities. In modern times, the theories of John Rawls and Robert Nozick are much quoted in studies regarding justice. However, Asian sensibilities call for a deeper exploration of justice for the purpose of harmony and that is the intent of this article.
\end{abstract}

\section{Keywords}

justice, Biblical justice, harmony, Asian sensibilities, reconciliatory justice, rehabilitative justice, restorative justice.

\section{INTRODUCTION}

In the late 60 s and right through to the 80 s, being involved in issues concerning justice was at the heart of the agenda in many organisations and institutions, including religious ones. The need to overthrow oppressive regimes, the upliftment of the poor, and combatting corruption were at the forefront of many activists. To some extent these issues attracted many young people, especially tertiary students to involve themselves in justice related issues. Even today, the word "justice" is on everyone's lips nowadays and may signify almost anything. Apart from just behaviour or treatment, justice is often seen as the quality of being fair and reason- 
able. However, the term justice is used in a broad sweep that can mean almost anything depending on the one who is using it. Given the broad usage of this word, some confusion can be expected when used in the ordinary sense.

From a historical point of view, the classical definition, which comes to us through Plato, Aristotle, Saint Ambrose, and Saint Augustine of Hippo, is expressed possibly in a single phrase: suum cuique, or "to each his own." It also finds a similar expression in the reformed code (Corpus Juris Civilis) initiated by Emperor Justinian I in the sixth century where it is stated that "Justice is a habit whereby a man renders to each one his due with constant and perpetual will."

In the Catholic tradition, justice is one of the four cardinal virtues which includes prudence, temperance, and fortitude. The Catechism of the Catholic Church defines justice as "the moral virtue that consists in the constant and firm will to give their due to God and neighbour. Justice toward God is called the "virtue of religion." Justice toward men disposes one to respect the rights of each and to establish in human relationships the harmony that promotes equity with regard to persons and to the common good. The just man, often mentioned in the Sacred Scriptures, is distinguished by habitual right thinking and the uprightness of his conduct toward his neighbour. "You shall not be partial to the poor or defer to the great, but in righteousness shall you judge your neighbour." "Masters, treat your slaves justly and fairly, knowing that you also have a Master in heaven." (\#1807).

In the Catechism of the Catholic Church, justice is viewed from a Thomistic and even an Aristotelian perspective of a moral virtue which is described as any positive personal qualities that lead a person to lead a good and pure life. In this sense, justice is seen in concrete action rather than an abstract concept.

The concept of justice is at the core of Catholic Social Teaching and it pervades the different aspects (themes) of the Church's involvement in the social life of the world. In fact, 'justice is the value that accompanies the exercise of the corresponding cardinal virtue'. ${ }^{1}$ John Paul II in his Encyclical Letter Sollicitudo Rei Socialis states that 'justice is particularly important in the present-day context, where the individual value of the person, his dignity and his rights - despite proclaimed intentions 
- are seriously threatened by the widespread tendency to make exclusive use of the criteria of utility and ownership'. ${ }^{2}$

\section{THEORIES OF JUSTICE}

The question of justice is not something new and it is not only the concern of Christians. This has been discussed over centuries and already in the Classical Period in Ancient Greece, the philosopher Aristotle offered a formal theory of justice where justice is defined, but no content is added. In simple terms, Aristotle presents justice as 'equals should be treated equally, and unequals unequally' (Nicomachean Ethics). In more recent studies in the West regarding of the theories of justice, two names probably stand out more than others, namely, John Rawls and Robert Nozick. It is against this framework that justice is interpreted for the modern world.

\section{Justice as Fairness}

John Rawls, who is described by some authors as the most notable and controversial political theorist of the twentieth century, gave great attention to a wide range of issues that are connected to political, moral, and social theory. In his early years, Rawls concentrated heavily on moral realism and also on social justice. "A central tenet in Rawls' philosophy is the sanctity of political rights and basic civil liberties. He stresses the importance of our privilege to choose our own paths to the future. Accordingly, Rawls also includes in this theory a duty of society to provide similar opportunities for every individual to achieve an equal level of happiness. He claims that no person should be put at a disadvantage based on an uncontrollable situation that he or she was born into."

John Rawls' starting point would be that in the state of the original position and behind the veil of ignorance, there would be a level of equality and those concerned will develop principles aimed at achieving equal liberty. It is in this state of equality that his two principles of justice would be agreed upon. Rawls' two principles of justice are developed in 'two stages' in his book. The first formulation of the two principles is:

2 Cf. John Paull II, Encyclical Letter Sollocitudo Rei Socialis (1988), 40.

3 Lynette Sweidel, 'John Rawls: A Brief Introduction', http: / /www.baylor.edu/lynette_sweidel/ RawlsPaper.html (access: 01.03.2019). 
First Principle: Each person is to have an equal right to the most extensive scheme of equal basic liberties compatible with a similar scheme of liberties for others.

Second Principle: Social and economic inequalities are to be arranged so that they are both (a) reasonably expected to be to everyone's advantage, and (b) attached to positions and offices open to all. $^{4}$

The final formulation of Rawls' two principles are as follows:

First Principle: Each person has an equal right to the most extensive total system of basic liberties compatible with a similar system of liberty for all.

Second Principle: Social and economic inequalities are to be arranged so that both: (a) to the greatest benefit of the least advantaged, consistent with the just saving principle, and (b) attached to offices and positions open to all under conditions of fair equality of opportunity. ${ }^{5}$

We can note two differences between the first formulation and the final one. The final formulation of the first principle states "the most extensive total system of equal basic liberties" in place of "the most extensive scheme of equal basic liberties" and the second difference is that in the final formulation of the second principle we find "to the greatest benefit of the least advantaged" in place of "to everyone's advantage". In other words, the final formulation seems to be more precise than the first formulation.

The first principle, along Kantian line, is often called the Liberty Principle (also known as Priority of Liberty). The liberty principle is related to the fact of planning one's own life. In a situation where there is less liberty, it would mean that some persons would have to sacrifice choice with regards to their plans for the future and exchange it for some other social good (e.g. greater income) ${ }^{6}$ This principle also provides for basic and universal respect for persons as a minimum standard for all just institutions. But while all persons may be morally equal, we also know that in the real world there are significant differences between

4 John Rawls, A Theory of Justice (Oxford: OU, 1999), 53.

5 John Rawls, A Theory of Justice, 266.

6 A. Loizou, "Theories of Justice: Rawls", in The Encyclopedia of Applied Ethics, IV, edited by Ruth Chadwick, Academic Press, San Deigo, 1998, p. 353. 
individuals. These differences under conditions of liberty will lead to social and economic inequalities. For Rawls, these inequalities are to be arranged to everyone's benefit, especially the least advantaged. Even within such a context, there can be no sacrifice of liberties, e.g., freedom of speech, thought, association, etc. ${ }^{7}$

The second principle is called the Difference Principle. What is this difference principle? According to Andros Loizou, the difference principle is "a principle according to which social and economic inequalities are to be arranged so as to be of maximum benefit to the least advantaged socio - economic sector". ${ }^{8}$ According to some commentators, the difference principle is the most distinctive part of Rawls' theory of justice. The question arises, 'What is the basis or source of such a principle which seems to exhibit some elements of Christianity?' There are some commentators of Rawls' works who attribute the basis of this principle to the Judeo-Christian tradition. But Rawls does not make reference to any religious or metaphysical basis for this principle. He calls them 'considered convictions' which are shaped by a variety of other factors. Because this principle is free of religious convictions (as Rawls claim it to be), Rawls sees this principle being convoked and accepted in today's situation. ${ }^{9}$

For Rawls, the above two principles apply to the basic structure of society and they govern the assignment of rights and duties and regulate the distribution of social and economic advantages. ${ }^{10}$ Is there a particular order to these two principles? Yes, since for Rawls these two principles are to be arranged in a serial order, i.e., the first principle is prior to the second. In other words, the first principle concerning equal liberty has always priority. In this sense, for someone like Rawls, the concept of equality is of great importance in setting out a theory of justice.

\section{Justice as Entitlement}

Nozick's entitlement theory of justice is based on "a strong notion of individual property, according to which no one has a right to anything unless he or she has obtained it by gift of transfer from someone else

\section{A. Loizou, "Theories of Justice: Rawls", 353}

A. Loizou, "Theories of Justice: Rawls”, 347

9 Cf. D.B. Forrester, Christian Justice and Public Policy (Cambridge: Cambridge University Press, 1997), 12.

${ }^{10}$ A. Loizou, “Theories of Justice: Rawls”, 53. 
who legitimately owns it, or unless he or she has been the first legitimate owner". ${ }^{11}$

Nozick's entitlement theory is based also on the idea that only free market exchanges respect people as equals - for him, as 'ends in themselves'. Indeed, even if a free market did not, for instance, produce the most overall well-being in Nozick's view it would be justified. According to Nozick, there are three sets of rules of justice defining how things not previously possessed by anyone may be acquired, how possession may be transferred from one person to another, and finally, what must be done to rectify injustices arising from these violations. Therefore, his theory is formulated in the following three principles:

First Principle: [Acquisition principle] - A person who acquires a holding in accordance with the principle of justice in acquisition is entitled to that holding.

Second Principle: [Transfer principle] - A person who acquires a holding in accordance with the principle of justice in transfer, from someone else entitled to the holding, is entitled to the holding.

Third Principle: [Rectification principle] - No one is entitled to a holding except by (repeated) applications of 1 and $2 .{ }^{12}$

Nozick holds that it is the right of an individual to acquire and transfer property. It is here that we see Nozick accepting a 'Lockean provisio' of the justice or original acquisition. If people's current holdings are justly acquired, then the transfer principle alone determines whether subsequent distribution are just. Consequently, any taxation over the amount required to preserving institutions of just transfer, acquisition and rectification, that is, preserving entitlements, , are unjust according to Nozick.

What is clear in Nozick's theory is that an individual is free to acquire by mixing labour with the capacity to purchase, as long as the individual who is acquiring does not hurt other persons in that same process. In other words, it is not just for the individuals to acquire something that is so limited that the acquisition of the product worsens the situation of others. The base line is that one has the right to own goods, but not when that ownership harms others.

11 A. Loizou, "Theories of Justice: Rawls", in The Encyclopedia of Applied Ethics, IV, edited by Ruth Chadwick, Academic Press, San Deigo, 1998, 359.

12 Robert Nozick, Anarchy, State and Utopia, 151 
What seems to be a good principle to follow, Nozick makes an exception. The key to Nozick's interpretation of this principle lies in these words: 'worsens the situation of others'. Nozick says that even though an individual may have something that another person may be in need of, if this product was created or acquired without actually worsening the situation of the other, then the individual is entitled to keep the product.

Nozick's understanding of justice is different from the utilitarian conception and also Rawls' conception of justice, i.e., it is neither for the greatest good of the greater numbers, nor is it for the protection of the least advantaged. For Nozick, it is unfortunate that there are some who are wealthier than the others. But this is neither unfair nor is it a moral instance. ${ }^{13}$ What we notice about this theory is that it is very individualistic. There is no concept of the difference principle because this would in turn be considered against the very foundation of Nozick's theory of the autonomy of the individual.

Clearly Nozick classifies theories of justice as (1) either an end result or historical; and (2) either patterned or un-patterned. The entitlement theory of Nozick is historical and un-patterned. It does not demand that the distribution resulting from just acquisition, transfer and rectification be patterned. It is clear that Nozick's theory of justice is neither a theory of social justice, nor is it a theory of distributive justice. ${ }^{14} 47$ Where Rawls sees the necessity for societal principles to ensure just distribution, Nozick rejects any role for the state in 'distributive justice'. Justice is limited to the 'commutative' sphere of individual exchanges and each is entitled to what is considered just to the person.

Whether justice is seen as fairness or as entitlement, it has its overtones on the Christian understanding of justice, though not with the same end in mind. These theories of justice do provide the foundation for a deeper exploration of the Christian view of justice and its implications on how God is perceived.

\section{TyPes OF Justice}

For most people, justice is action in accordance with the requirements of some law. Whatever the foundation of this justice may be, their

13 Cf. Raphael Gallagher, 'Il Bene, i diritti e la giustizia', Academia Alfonsiana, Rome, 1999 2000,58 .

14 Cf. Raphael Gallagher, 'Il Bene, i diritti e la giustizia', 57. 
expressions of justice are often grounded in human consensus or societal norms. In doing so, justice is supposed to ensure that all members of society receive fair treatment. One must bear in mind that issues of justice arise in several different spheres and each of the different spheres expresses the principles of justice and fairness in its own way, resulting in different types and concepts of justice. ${ }^{15}$

The word 'justice' is used in many situations and there is a possibility that one may intend to use it for a particular purpose, but the audience may understand it to mean something else. In that sense, this word 'justice' could be quite ambivalent and sometimes used interchangeably unless the one who uses it makes it clear from the start. So, what "types" of justice are there to begin with?

The most fundamental principle of justice-one that has been widely accepted since it was first defined by Aristotle -is the principle that "equals should be treated equally and unequals unequally." One also needs to bear in mind that Aristotle was of the view that it is unjust to treat unequal things equally.

In Aristotelian ethics, there are three "types" of justice: ${ }^{16}$

1. Compensatory justice: Refers to the extent to which people are fairly compensated for their injuries by those who have injured them; just compensation is proportional to the loss inflicted on a person.

2. Retributive (Punitive) justice: Refers to the extent to which punishments are fair and just. In general, punishments are held to be just to the extent that they take into account relevant criteria such as the seriousness of the crime and the intent of the criminal, and discount irrelevant criteria.

3. Distributive justice: Refers to the extent to which society's institutions ensure that benefits and burdens are distributed among society's members in ways that are fair and just.

In more recent times, it is commonly accepted that there are four "types" of justice: ${ }^{17}$

15 Michelle Maiese, “Types of Justice”, https://beyondintractability.org/essay/types-of-justice, (access: 03.04.2019).

${ }^{16}$ Cf. Manuel Velasquez, Claire Andre, Thomas Shanks, S.J., and Michael J. Meyer, "Justice and Fairness",https://www.scu.edu/ethics/ethics-resources/ethical-decision-making/justice-and-fairness, (access: 25.03.2019).

17 “Justice." Merriam-Webster.com. 2011. https://www.merriam-webster.com (27.04.2019). 
1. Commutative justice: that which bears on the relations between individuals especially in respect to the equitable exchange of goods and fulfilment of contractual obligations.

2. Distributive justice: that which is concerned with the apportionment of privileges, duties, and goods in consonance with the merits of the individual and in the best interest of society.

3. Legal justice: that which results in a fair and proper administration of the law.

4. Social justice: that which promotes the common good.

The above theories of justice portray primarily the ideas of fairness, and for most people, the essence of fairness as treating people equally. However, theories and concepts of justice are often complex and multifaceted. For this reason then, justice with Asian sensibilities need to be modelled after divine justice.

\section{Biblical Justice}

In a secular sense, justice is often defined as "the process or result of using laws to fairly judge and punish crimes and criminals," 18 and perhaps most of us understand and even apply justice in this way - something that is served, deserved, that which sets the universe right. However, in the Christian tradition, the understanding of justice is similar in some ways but yet different in other ways.

To understand the concept of justice in the Bible, one has to look at the Hebrew word for "justice," mishpat. Bible scholars say that this word occurs with its variants more than two hundred times in the Hebrew Old Testament alone. Its most basic meaning is: (1) to treat people equitably; (2) Acquitting or punishing every person on the merits of the case, regardless of race or social status; (3) Anyone who does the same wrong should be given the same penalty. ${ }^{19}$ Closely connected to mishpat is also the idea of "righteousness" (sedaqa). In the Bible, both sedaqa and mishpat can often be understood in legalistic terms. ${ }^{20}$

One must also keep in mind that justice (mishpat) does not confine itself to merely the punishment of wrongdoing since in the Bible justice also looks at

\footnotetext{
"Justice." Merriam-Webster.com..

19 Cf. Tim Keller, 'What Is Biblical Justice?', https://relevantmagazine.com/god/what-biblical-justice, (access: 24.03.2019).

20 Michelle Tooley, "Just, Justice," in Eerdmans Dictionary of the Bible (Michigan: William B. Eerdmans Publishing Company, 2000), 757.
} 
giving people their rights. In this context then, the marginalised and the underprivileged are significant in the social agenda of these ancient communities. In fact, the Hebrew word for justice is often paired with the word for righteousness, indicating that "righteousness" is about more than personal piety; it's a sense that things are right for the communal whole - a sense of justice and rightness. ${ }^{21}$

If the Old Testament then follows the classical conception of justice as suum cique (to each what is due), the New Testament concept of justice is now, redefined by the coming of Jesus Christ, the Incarnation. It is through his incarnation, life, death, resurrection, and ascension, Jesus is literally God's revelation of Godself - God's will, God's love, God's justice - to the cosmos. In other words, Jesus exposes the character of God. His incarnation brings forth a transformative impact on both the religion and globe. ${ }^{22}$

One has to remember that biblical justice goes beyond the legal framework because it involves bringing the individuals, communities, and the cosmos towards wholesomeness, by upholding both goodness and impartiality. In this sense, "justice is rooted in God's character (Isa. 5:16; Deut. 32:4), and justice is what God demands of followers. The prophets constantly call on the community to recognise God as the God of justice and also towards repentance which then leads to wholesomeness.

\section{Justice of God And Asian Sensibilities}

In the Old Testament, the authors often speak of a God of justice and in some ways depict God as the one who rewards the good and punishes the bad. However, the very nature of God is love as seen in the New testament. In this sense, there cannot be a dichotomy for a loving yet punishing God. Justice and love flow from God's heart and character. In other words, God seeks to make the object of His holy love whole and this is what motivates God throughout the Old and New Testaments. God cannot be simply boxed to conform to the secular concepts of iustitia vindicativa (retributive justice), iustitia legalis (legal justice) or even iustitia distributiva (distributive justice).

21 Amanda Mootz, Seeking Biblical Justice, http:/ / www.worldvisionadvocacy.org/2015/01/01/ seeking-biblical-justice (access: 24.03.2019)

22 T.S. Hassell T.S., "Justice and Religion: Christianity," in Encyclopaedia of Global Justice (Springer: Dordrecht, 2011. 
In the history of Christianity, 'the picture of a punitive and avenging God has thrown many people into a state of anxiety about eternal salvation'. ${ }^{23}$ Kasper proposes that 'God's justice is His mercy... Mercy must be understood as God's own justice and His holiness. Only in this sense can we make the image of the good and merciful father, whom Jesus proclaimed to us, shine again". ${ }^{24}$ The "vindictive" model of a God of the Old Testament is replaced with a compassionate God of the New Testament made manifest through the person of Jesus Christ. However, both in the Old and New Testament it is clear that God is just, He loves justice, He does justice, and He commands justice.

The secular concepts of justice are often used to describe God's justice but He transcends all human description of a God who is just and righteous in more ways than one. It is perhaps the limitation of the description that often God is reduced as one who is vindictive in His just nature. In the New Testament, Jesus is seen as a just person but yet He manifests the justice of God in a different way as compared the dominant model in the Old Testament. In the context of this exploratory discussion, I have chosen the account of Jesus' encounter with the Samaritan woman (John 4:1-42) as the basis for Asian sensibilities in reference to justice.

\section{Reconciliatory Justice.}

As much as justice has been explored as doing or giving what each person is due, Jesus, in His public ministry exemplifies other aspects of God's justice and one among them is reconciliatory justice. In this context, reconciliation here often refers to "change". "Reconciliation involves a change in the relationship between God and man or man and man. It assumes there has been a breakdown in the relationship, but now there has been a change from a state of enmity and fragmentation to one of harmony and fellowship." 25

The work of reconciliation was at the heart of Jesus' ministry and there are many accounts of this in the gospels. One such example would be the encounter at the well between Jesus and the Samaritan woman

23 Walter Kasper, Mercy:The Essence of the Gospel and the Key to Christian Life (New York: Paulist Press, 2013), 12.

24 Walter Kasper, Mercy:The Essence of the Gospel..., 12, 13.

25 Cf. William J. Woodruff, "Reconciliation" (1997). https://www.biblestudytools.com/dictionaries/bakers-evangelical-dictionary/reconciliation.html, (access: 3 April 2019). 
as described in Chapter 4 of John's gospel. The whole conversation between Jesus and this woman was to effect change in her and this process included the need for her to be reconciled with God and herself. Justice in the ordinary or categorical sense would have meant that this woman would have had to pay her dues before God for the kind of life she lived. However, the intense conversation leads to the path of reconciliation.

The reconciliation that we see in this encounter is threefold: ${ }^{26}$

1. Individual Reconciliation: In order to rebuild lives and relationships with others, an individual would have to start with reconciling with themselves. The conversation between Jesus and the Samaritan woman leads to her acknowledging her present state and the articulation of that in itself begins the process of individual reconciliation.

2. Interpersonal Reconciliation: Interpersonal reconciliation calls for an acknowledgement of past wrongs and the recognition of the need to be reconciled with God. The Samaritan woman in the course of the conversation recognises the need for God.

3. Communal Reconciliation: Here reconciliation focuses on relations between groups - social, political, ethnic, religious, or other-in divided societies, leading towards mutual acceptance and respect.

\section{Rehabilitative Justice.}

In an ordinary sense, to rehabilitate would mean to assist someone to return to a previous or original state. Once again, change is implied when one speaks of rehabilitation. The purpose of rehabilitative justice is to reconnect with those things that would help a person to function optimally - physically, emotionally and in this context, spiritually. To rehabilitate in this context would mean to help the person with the goal of reintegrating back into society.

The rehabilitation that is required in this context can be seen at three different levels:

1. Cognitive Rehabilitation: Cognitive rehabilitation is a system of therapeutic activities, based on brain-behaviour relationships, directed to achieve functional change. Because the Samaritan woman had withdrawn from being involved with her communi-

26 Cf. Paul Seils, “The Place of Reconciliation in Transitional Justice," International Center for Transitional Justice (28.06.2017). https://www.ictj.org/publication/reconciliation-transitional-justice (access 05.04.2019) 
ty, she now needs to change her way of thinking so as to be able to function optimally in a social context within the community.

2. Emotional Rehabilitation: In order to help people, overcome anger, denial, and even trauma, emotional rehabilitation is required. This would be a journey to recover and return persons to their prior state. The emotional scars that the Samaritan woman would carry with her requires rehabilitation (healing) and this would facilitate the restoration of her original state.

3. Spiritual Rehabilitation: Crucial to the process of rehabilitation is also a spiritual rehabilitation. As mentioned earlier, rehabilitation or healing is a journey that requires patience. It takes time and sometime painful time. "Developing spirituality and attuning ourselves to the highest influences of godliness are not an easy matter. It takes time and frequently involves a struggle." ${ }^{27}$ The Samaritan woman who probably had alienated herself from God now needs to embrace this journey back to God and therefore, spiritual rehabilitation is a necessary pathway.

\section{Restorative Justice}

Primarily, restorative justice emphasises repairing the harm caused by an individual or a group towards another. Through effective cooperative processes, this can lead to transformation of people, relationships and communities. ${ }^{28}$ In short, restorative justice provides the person who caused the harm, people who were affected by the harm, and the community to create a meaningful solution. The concept of restorative justice that is being explored here has as its objective for the "offender" to be reinserted back into the community and for the community to accept this person. Though restorative justice may not be applicable to all situations, the ultimate goal to which we need to strive for is to restore a sense of equilibrium for all persons connected.

In this context, restorative justice is quite different from that which is being spoken about generally within a legal framework. There it is about bringing the offender and the one who has been offended together and to seek ways to resolve the situation. Here, we look at justice having a social value to both the individual and the community: "All social

27 Howard W. Hunter, "Blessed from on High”. Ensign 09/1988, 61.

28 Cf. Centre for Justice and Reconciliation, "What is Restorative Justice?" http://restorativejustice.org/ restorative-justice/about-restorative-justice/tutorial-intro-to-restorative-justice/ lesson-1-what-is-restorative-justice/\#sthash.IntCnqy2.dpbs (access 05.04.2019). 
values are inherent in the dignity of the human person, whose authentic development they foster. Essentially, these values are: truth, freedom, justice, love." 29

\section{Asian Sensibilities}

Historically, the concept of justice has been developed on the grounds of philosophy, theology and even religion and because of its interdisciplinary nature, the concept of justice often differs in every culture. Though justice itself includes concepts of moral correctness that is based on ethics, rationality, law, religion, equity and fairness, what is often missing is the individual and the community. Even if they are included, it is seen from the narrow perspective of rights and that which is just from a juridical perspective. Much of the concepts of justice have been based on early theories of justice that were set out by the Ancient Greek philosophers, e.g., Plato in his work The Republic, and Aristotle in his Nicomachean Ethics. These were the foundations on which people like John Locke, John Stuart Mills, John Rawls and Robert Nozick have built their theories of justice. As one author puts is, "Western society strives to find and prove 'the truth', while Eastern society accepts the truth as given and is more interested in finding the balance. Westerners put more stock in individual rights; Easterners in social responsibly." 30

Different from these western theories, the Biblical understanding of justice, though it includes concepts like equity and fairness, there are other dimensions that are often not explored, especially that of wholesomeness. Key towards having an "Asian understanding" of justice is also finding a pathway towards a harmony that enjoins the individual, community, cosmos and God. Justice does not need to mean retribution or revenge in any form. Whether it is resolving conflict or finding ways to heal pain, justice needs to move towards harmony. It must be remembered that 'two wrongs do not make a right' and therefore justice must prevail over the ideas of rights or even revenge. The following story best illustrates the idea of harmony as being a character of justice.

"Two boys were caught fighting. The town "judge," a man chosen by the community for his wisdom and leadership, told the boys they had to

29 Cf. Second Vatican Ecumenical; Council, Pastoral Constitution Gaudium et Spes, 26: AAS 58 (1966), 1046-1047,

30 "East vs West: Philosophy, Cultural Values and Mindset". http://www.1000ventures.com/ business_guide/ crosscuttings/cultures_east-west-phylosophy.html (access 01.05.2019). 
finish their work that day with their legs tied together. They would have to learn to work together. Then they had to learn a prayer by heart from the other's religion. What happened? The two boys became best friends. No prison time. No elaborate court proceeding. No taking a bad situation and making it worse. Just some common sense, creativity and a clear goal: harmony." 31

Harmony and justice are not only qualities for human and societal growth, but they can be foundations for building a just society. To this just society can be added other positive goals that can serve to resolve conflicts and crises. Plato wrote in The Republic that when a person is unjust, there is no harmony and that justice must impart harmony and friendship: "Justice in the individual is now defined analogously to justice in the state. The individual is wise and brave in virtue of his reason and spirit respectively: he is disciplined when spirit and appetite are in proper subordination to reason. He is just in virtue of the harmony which exists when all three elements of the mind perform their proper function and so achieve their proper fulfilment; he is unjust when no such harmony exists."

\section{Conclusion}

In an era where revenge and terror seem to prevail, especially in the name of religion, we need to rethink the character of justice. The Bible places equal emphasis on both mercy and justice as God's character - something that humans will find it hard to practise. But nonetheless, justice with Asian sensibilities must transcend the categorial nature of Greek philosophies. If justice is God's nature, then so are mercy and compassion because God cannot be the former without the latter.

Human justice must seek to resemble more like Divine justice and the very nature of that divine justice is mercy and compassion. The cry for justice that is frequently heard in this world and seeking for a response to the unjust relationships in our world must be met with compassion and mercy. ${ }^{32}$ Pope Benedict, when speaking about divine justice said, "In reality, [the] classical definition does not specify what 'due' is to be rendered to each person... What man needs most cannot be guaranteed to him by law. In order to live life to the full, something more intimate

31 Cf. Huffington Post, “Our Justice System Should Promote Harmony, Not Revenge." https:// www.huffpost.com/ entry/matthew-cooke-and-adrian_b_5459298 (access 24.04.2019).

32 Kasper, 17. 
is necessary that can be granted only as a gift: we could say that man lives by that love which only God can communicate since He created the human person in His image and likeness." ${ }^{33}$

In today's context, whether it is commutative, distributive, legal or social justice, all must lead towards an integral harmony within the person and in the community. Despite the vast diversity that is seen in Asia, family and community have great importance in the Asian culture. In that sense, justice must seek ultimately to reconnect the individuals with themselves, the others, the cosmos and with the Divine. Only then can justice be said to be complete. Justice with Asian sensibilities offers us the path towards integration and harmony and ultimately, peace.

Justice towards harmony can be an opportunity to build bridges and promote interreligious engagement. In a world that is becoming more polarised than before, harmony can be a goal that all communities strive for and in that process, injustices may be overcome by this common good. Interreligious engagement is core to the Asian ethos because of the diversity of cultures and religions. In speaking about the divine justice, one cannot exclude the need to overcome unjust situations in the corporeal world and interreligious engagement towards harmony can be a tool towards this: "Common action for justice is not merely a context for, but an expression, of interreligious relationships." ${ }^{34}$ For this reason then, rethinking the justice of God with Asian sensibilities may provide the pathway towards an integrated and harmonious living - a world that seeks to rehabilitate, reconcile and restore the 'reign of God' in Asian soil.

33 Pope Benedict XVI, “Message of His Holiness Pope Benedict XVI” for Lent 2010” (30.10.2009). http://w2. vatican.va/content/benedict-xvi/en/messages/lent/documents/hf_ben-xvi_ mes_20091030_lent-2010.html (access 25.04.2019)

34 Michael Amaladoss, "Interreligious Dialogue: A View from Asia," in International Bulletin of Missionary Research (January 1995). http: / / www.internationalbulletin.org/issues / 1995-01 / 1995 01-002-amaladoss.pdf (access 30.04.2019). 


\section{BibLIOGRAPHY}

Abbott, Walter M (Ed.). "Pastoral Constitution Gaudium et Spes" (7 December 1965), in The Documents of Vatican II. New York: America Press, 1966.

Amaladoss, Michael. "Interreligious Dialogue: A View from Asia," in International Bulletin of Missionary Research (January 1995). http://www.internationalbulletin.org/issues/1995-01/1995-01-002-amaladoss.pdf

Aquinas, Thomas. Summa Theologica. Translated by Fathers of the English Dominican Province. Benziger Bros. ed. Westminster, MD: Christian Classics,1947. http://www.ccel.org/ccel/ aquinas/summa.html.

Centre for Justice and Reconciliation, "What is Restorative Justice?" http://restorativejustice.org/ restorative-justice/about-restorative-justice/tutorial-intro-to-restorative-justice/ lesson-1-what-is-restorative-justice/\#sthash.IntCnqy2.dpbs.

Forrester, Duncan B. Christian Justice and Public Policy. Cambridge: Cambridge University Press, 1997.

Freedman, David Noel (Ed.). Eerdmans Dictionary of the Bible. Michigan: William B. Eerdmans Publishing Company, 2000.

Gallagher, Raphael. 'Il Bene, i diritti e la giustizia'. Rome: Academia Alfonsiana, 1999.

Hassell, T.S. "Justice and Religion: Christianity," in Encyclopaedia of Global Justice., edited by Deen K. Chatterjee. Springer: Dordrecht, 2011.

Huffington Post. "Our Justice System Should Promote Harmony, Not Revenge." https://www.huffpost.com/ entry/matthew-cooke-and-adrian_b_5459298.

Hunter, Howard W. "Blessed from on High", Ensign 09/1988.

John Paull II, "Encyclical Letter Sollocitudo Rei Socialis (1988)". http://w2. vatican.va/content/john-paul-ii/en/encyclicals/documents/hf_jp-ii_ enc_30121987_sollicitudo-rei-socialis.html.

Kasper, Walter. Mercy: The Essence of the Gospel and the Key to Christian Life. New York: Paulist Press, 2013.

Keller, Tim. "What Is Biblical Justice?", https://relevantmagazine.com/god/ what-biblical-justice.

Lebacqz Karen. Six Theories of Justice: Perspectives from Philosophical and Theological Ethics. Minneapolis: Augsburg Publishing House, 1987.

Loizou, A. "Theories of Justice: Rawls", in The Encyclopedia of Applied Ethics 
Vol. IV, edited by Ruth Chadwick. San Deigo: Academic Press, 1998.

Maiese, Michelle. "Types of Justice”, https://beyondintractability.org/essay/typesof-justice.

Merriam-Webster.com.2011. https://www.meriam-webster.com.

Mootz, Amanda. "Seeking Biblical Justice". http://www.worldvisionadvocacy.org/ 2015/01/01/seeking-biblical-justice.

Nozick, Robert. Anarchy, State and Utopia. New York: Basic Books Inc., 1974.

Pontifical Council for Justice and Peace, Compendium of the Social Doctrine of the Church. London: Burns \& Oates, 2004.

Pope Benedict XVI, "Message of His Holiness Pope Benedict XVI" for Lent 2010" (30.10.2009). http://w2. vatican.va/content/benedict-xvi/en/messages/ lent/documents/hf_ben-xvi_mes_20091030_lent-2010.html.

Rawls, John. A Theory of Justice (Revised Edition). Oxford: Oxford University Press, 1999.

Seils, Paul. "The Place of Reconciliation in Transitional Justice," International Center for Transitional Justice (28.06.2017). https://www.ictj.org/publication/reconciliation-transitional-justice.

Sweidel, Lynett. "John Rawls: A Brief Introduction",http://www.baylor.edu/lynette_sweidel/ RawlsPaper.html

Tooley, Michelle. "Just, Justice," in Eerdmans Dictionary of the Bible, edited by David Noel Freedman. Michigan: William B. Eerdmans Publishing Company, 2000.

Velasques, Manuel, Claire Andre, Thomas Shanks, S.J., and Michael J. Meyer. "Justice and Fairness", https://www.scu.edu/ethics/ethics-resources/ ethical-decision-making/justice-and-fairness.

Woodruff, William J. "Reconciliation". https://www.biblestudytools.com/dictionaries/bakers-evangelical-dictionary/reconciliation.html.

. "East vs West: Philosophy, Cultural Values and Mindset". http:// www. 1000ventures.com/business_guide/ crosscuttings/cultures_ east-west-phylosophy.html. 